\title{
PENGARUH STRATEGI BLENDED LEARNING TERHADAP HASIL BELAJAR MATA KULIAH SEJARAH PENDIDIKAN ISLAM PADA MAHASISWA YANG MEMILIKI LOCUS OF CONTROL BERBEDA
}

\author{
SIHABUDIN \\ Fakultas Tarbiyah dan Keguruan UIN Sunan Ampel Surabaya \\ Email: budinsihab77@gmail.com
}

\begin{abstract}
Abstrak. Tujuan penelitian ini adalah untuk menguji: (1) perbedaan perolehan hasil belajar (mengingat dan memahami konsep dan fakta) mahasiswa yang dibelajarkan dengan strategi pembelajaran blended learning dan strategi pembelajaran face to face (tatap muka secara langsung), (2) perbedaan hasil belajar (mengingat dan memahami konsep dan fakta) mahasiswa yang memiliki internal locus of control dan mahasiswa yang memiliki external locus of control, (3) interaksi antara penggunaan strategi pembelajaran blended learning dan face to face dengan locus of control terhadap hasil belajar (mengingat dan memahami konsep dan fakta) mata kuliah Sejarah Pendidikan Islam. Penelitian ini menggunakan metode a factorial (2x2) version of non equivalent control group design dengan mengambil tempat penelitian di UIN Sunan Ampel Surabaya yang dilaksanakan pada semester ganjil 2015/2016. Subjek penelitian sebanyak 124 orang pada semester 3 Fakultas Tarbiyah dan Keguruan Program Studi Pendidikan Agama Islam (PAI) dan Program Studi Pendidikan Guru MI (PGMI) yang tersebar dari 4 rombongan belajar (rombel) yang terbagi dalam 2 kelompok kelas eksperimen dan 2 kelompok kelas kontrol. Penetapan kelas eksperimen dan kelas kontrol dilakukan dengan teknik acak. Instrumen pengumpulan data menggunakan teknik angket dan tes. Subjek yang dianalisis berjumlah 84 pebelajar berdasarkan pada 33\% kelompok internal locus of control dan 33\% external locus of control, dengan menggunakan Analysis of Variance (ANOVA) $2 \times 2$. Hasil penelitian menunjukkan, bahwa: 1) Perolehan hasil belajar (mengingat dan memahami konsep dan fakta) mata kuliah Sejarah Pendidikan Islam antara kelompok mahasiswa yang dibelajarkan dengan strategi pembelajaran blended learning (face to face, online dan offline) dan strategi pembelajaran face to face (tatap muka secara langsung) menunjukkan adanya perbedaan yang signifikan. Hal ini dapat dibuktikan dengan nilai $F_{\text {hitung }}=98,880$ dengan nilai probabilitas $(p)=0,000$. 2) Perolehan hasil belajar (mengingat dan memahami konsep dan fakta) mata kuliah Sejarah Pendidikan Islam antara kelompok mahasiswa yang memiliki internal locus of control dan kelompok mahasiswa yang memiliki external locus of control menunjukkan adanya perbedaan yang signifikan, yang ditunjukkan dengan nilai $F_{\text {hitung }}=36,950$ dengan nilai probabilitas $(p)=0,000,3)$ Tidak terdapat pengaruh interaksi antara strategi pembelajaran blended learning (Face to face, online dan offline), strategi pembelajaran face to face (tatap muka secara langsung), dan locus of control terhadap hasil belajar (mengingat dan memahami konsep dan fakta) Sejarah Pendidikan Islam, yang dibuktikan dengan perolehan nilai $F_{\text {hitung }}=2,955$ dengan nilai probabilitas $(p)=0,089$.
\end{abstract}

Kata Kunci: strategi pembelajaran blended learning, locus of control, perolehan hasil belajar. 


\section{PENDAHULUAN}

Pada era internet saat ini, kelas tradisional dengan pembelajaran face-toface tidak lagi cukup untuk dipertimbangkan sebagai satu-satunya pembelajaran yang paling baik. Metode pembelajaran berpusat pada pembelajar diprediksi tidak akan dapat mempersiapkan pebelajar untuk menghadapi tantangan masa depan yang akan dihadapi oleh pebelajar (Williams, 2010). Padahal, pendidikan dan pembelajaran dimaksudkan untuk mempersiapkan pebelajar hidup pada masa yang akan datang dan berhasil menghadapi tantangan hidup pada masa yang akan datang.

Tantangan yang akan dihadapi sekolah masa depan menurut Smaldino, Lowther, \& Russel (2008) adalah untuk menciptakan lingkungan pendidikan yang dapat memperluas dan meningkatkan kemampuan "digital natives" (pebelajar sebagai pemilik era digital). Selain itu, tantangan selanjutnya adalah untuk memperkuat pebelajar dengan keterampilan dan pengetahuan yang dibutuhkan agar dapat berhasil dalam masyarakat global. Chew (2008) menunjukkan dua tantangan yang akan dihadapi pembelajar dan pebelajar pada tren pembelajaran masa depan, yaitu: 1) pembelajar dan pebelajar mempunyai ide yang berbeda mengenai tujuan yang diharapkan, 2) pembelajar dan pebelajar semestinya menjaga fleksibilitas dan imajinasi terhadap alat-alat baru yang dapat digunakan.

Aspek yang penting dari lingkungan pembelajaran saat ini adalah bahwa pebelajar lebih beragam dari pada sebelumnya. Populasi yang terkait dengan etnisitas, status sosial, pengharapan, dan proporsi peserta didik yang belajar secara non-tradisional semakin meningkat. Lembaga pendidikan sekarang ini ditantang tidak hanya oleh cepatnya perkembangan teknologi informasi dan komunikasi, tetapi juga oleh karakter non- tradisional dari pebelajar itu sendiri. Perubahan demografi dan ekspektasi pebelajar, demikian juga inovasi teknologi dan agenda yang mendesak dari belajar sepanjang hayat merupakan transformasi perguruan tinggi abad ke-21 (Inoue, 2010).

Blended learning merupakan bentuk pembelajaran yang memberikan kemudahan pembelajaran dengan menggabungkan berbagai cara penyampaian, model pembelajaran, dan gaya pembelajaran, serta mengenalkan berbagai pilihan media dialog antara fasilitator dengan orang yang mendapat pembelajaran. Secara lebih spesifik, dapat dikatakan bahwa blended learning merupakan bentuk pembelajaran yang menggabungkan antara face to face dengan pembelajaran online dan pembelajaran offline (Bender \& Vredevoogd, 2006).

Blended learning dipilih sebagai strategi pembelajaran dan merupakan variabel perlakuan dalam penelitian ini disebabkan beberapa alasan sebagai berikut: 1) Blended learning merupakan bentuk strategi pembelajaran terbaru yang dapat mengakomodasi kebutuhan belajar pebelajar sebagai digital natives pada masa yang akan datang sebagaimana pendapat para pakar pembelajaran di atas, 2) Blended learning merupakan strategi pembelajaran yang dapat mengurangi keterbatasan-keterbatasan pada interaksi pembelajaran baik yang bersifat sinkronous maupun asinkronous disebabkan blended learning merupakan penggabungan antara kedua bentuk interaksi pembelajaran tersebut, 3) Blended learning dapat membantu para pembelajar dalam mengatasi keterbatasan waktu dan jarak, 4) Blended learning merupakan strategi pembelajaran yang variatif dilihat dari segi interaksinya.

Mata kuliah Sejarah Pendidikan Islam dipandang sebagai mata kuliah yang penting untuk dipelajari mahasiswa fakultas Tarbiyah dan Keguruan sebagai bagian dari mata kuliah Keilmuan dan 
keterampilan (MKK). Mata kuliah ini dimaksudkan untuk memberikan bekal pengetahuan dan pemahaman kepada mahasiswa fakultas Tarbiyah dan Keguruan dalam merefleksikan sistem pendidikan Islam masa lampau untuk kemudian diambil pelajaran dalam mereformulasikan sistem pendidikan Islam masa kini. Qasim, A., (2014) menyatakan bahwa mata kuliah sejarah adalah dimaksudkan untuk membantu generasi masa kini agar memiliki pengetahuan dan pemahaman yang baik mengenai kejadian masa lalu dan dapat mengambil manfaat dari masa lalu. Pengetahuan dan pemahaman mengenai masa lampau juga diharapkan dapat digunakan untuk merencanakan masa depan yang lebih bermakna untuk semua. Namun, pembelajaran sejarah seringkali menghadapi berbagai kendala. Di antara kendala yang sering muncul adalah mata pelajaran ini cenderung kurang disukai oleh pebelajar karena dituntut untuk banyak mengingat fakta-fakta sejarah. Hasil belajar mata pelajaran Sejarah juga cenderung rendah.

Untuk mendapatkan performansi dan hasil belajar yang baik di kelas, pembelajar tidak hanya perlu memberikan strategi pembelajaran yang baik, tetapi pembelajar juga perlu memperhatikan keunikan karakter dan perbedaan individual pebelajar (Dunn, 2001). Gagne, Wager, Golas \& Keller (2005) menjelaskan bahwa tugas-tugas belajar yang diberikan oleh pembelajar senantiasa dikerjakan oleh pebelajar berdasarkan perbedaan individual yang demikian besar dalam lingkup dan detailnya seperti perbedaan kemampuan alaminya (native ability), latar belakang pengetahuan dan pengalamannya, serta motivasinya untuk belajar.

Lebih jauh Gagne, Wager, Golas \& Keller (2005) menjelaskan bahwa faktorfaktor yang dapat mempengaruhi pembelajaran adalah: 1) faktor motivasi yang terdiri dari motivasi instrinsik dan motivasi ekstrinsik, 2) faktor perkembangan psikologis dan sosial yang terdiri dari perkembangan kognitif dan cara mengakomodasi bentuk belajar dalam desain pembelajaran, 3) faktor perbedaan individual yang terdiri dari pengaruh individual dan lingkungan seperti preferensi gaya belajar, strategi perolehan belajar, nilai-nilai sosial dan budaya, dan ekspektasi terhadap tujuan pembelajaran. Schunk, Pintrich, \& Meece (2010) menjelaskan bahwa salah satu perbedaan individual (individual differences) yang paling konsisten terkait dengan pembentukan atribusi individu adalah locus of control yang menunjuk pada kecenderungan seseorang (internal) untuk merasakan keterkaitan antara perilaku dan hasil, dan kecenderungan orang lain (eksternal) untuk merasakan bahwa tidak ada hubungan yang kuat antara perilaku dan hasil. Oleh karena itu, karakteristik pebelajar yang hendak diuji dan diteliti sebagai variabel moderator atau variabel yang turut mempengaruhi variabel bebas adalah locus of control.

Locus of control adalah sebuah kepribadian seseorang yang senantiasa mangaitkan tanggung jawab kegagalan atau keberhasilannya pada faktor internal atau faktor eksternal. Seseorang yang mempunyai internal locus of control berarti seseorang yang mempunyai kepercayaan bahwa keberhasilan atau kegagalannya disebabkan oleh usaha atau kemampuannya sendiri. Sebaliknya, seseorang yang mempunyai external locus of control berarti seseorang yang mempunyai kepercayaan bahwa faktorfaktor luar seperti keberuntungan, tugas yang sulit, atau perilaku orang lain yang menyebabkan keberhasilan atau kegagalannya (Slavin, 94).

Beberapa peneliti telah menemukan bahwa pebelajar yang mempunyai internal locus of control telah mendapatkan peringkat dan skor hasil belajar yang lebih tinggi dibanding dengan pebelajar yang mempunyai external locus of control meskipun mereka memiliki intelegensi yang sama (Lefcourt, 1976; 
Nowicki et al., 1978; Wilhite, 1990). Brookover et al., (1979) menemukan bahwa selain kemampuan, locus of control merupakan prediktor yang paling penting bagi prestasi akademik pebelajar. Erez,T.A.J.A, Bono J.E, dan Thoresen C.J (2002) menyatakan bahwa tidak ada lagi studi psikologi kepribadian yang lebih luas dari pembahasan mengenai self-esteem, locus of control, dan neuroticsm. Terdapat lebih dari 50.000 studi pada bidang-bidang ini.

\section{Tinjauan Pustaka}

Blended learning (BL), yang kadang-kadang disebut hybrid instruction (pembelajaran hybrid), atau blended instruction (pembelajaran blended) adalah penggabungan dan penyesuaian berbagai setting pembelajaran yang dimaksudkan untuk memenuhi kebutuhan belajar pebelajar. Sedangkan pembelajaran jarak jauh berbasis blended adalah sebuah penggabungan dari model setting synchronous (seperti face-to face atau video real time) dan suasana pembelajaran model asynchronous (Smaldino, Lowther, \& Russell, 2008). Pada umumnya, blended learning didefinisikan sebagai lingkungan belajar yang dilakukan dengan menggabungkan pembelajaran face-to-face dengan pembelajaran bermediasi komputer (computer mediated instruction) (Bonk \& Graham, 2006).

Gagne, Wager, Golas, \& Keller (2005) menjelaskan bahwa blended learning merupakan produk atau program pelatihan yang menggabungkan beberapa metode penyampaian yang berbeda seperti kolaborasi software (perangkat lunak), pembelajaran online, sistem yang didukung oleh kinerja elektronik, dan praktek mamajemen pengetahuan. Blended learning juga dapat digambarkan sebagai strategi pembelajaran yang mencampur berbagai aktivitas yang berdasar pada kejadian (event-based activities) termasuk kelas face-to-face, pembelajaran online secara sinkronous, dan pembelajaran mandiri.

Dziuban, Hartman, \& Moskal (2004) memberi catatan terkait dengan defenisi blended learning bahwa blended learning seharusnya dipandang sebagai sebuah pendekatan pedagogis yang mengkombinasikan efektivitas dan peluang sosialisasi di kelas dengan teknologi yang mungkin dapat meningkatkan belajar aktif dalam lingkungan online. Dengan kata lain, blended learning seharusnya didekati tidak hanya sebatas konstruk temporal, tetapi lebih sebagai sebuah dasain ulang yang mendasar terhadap model pembelajaran dengan karakteristik sebagai berikut: 1) blended learning dipandang sebagai sebuah peralihan dari metode ceramah menuju pembelajaran yang berpusat pada pebelajar di mana pebelajar menjadi pebelajar yang aktif dan interaktif, 2) blended learning dimaksudkan untuk meningkatkan interaksi antara pebelajar dengan guru, pebelajar dengan pebelajar, pebelajar dengan isi materi, dan pebelajar dengan sumber-sumber yang lain, 3) dalam blended learning, mekanisme penilaian formatif dan sumatif dirancang secara terintegrasi bagi pebelajar dan pembelajar.

Dalam hasil penelitiannya, Driscoll (2002a) mengidentifikasi empat macam konsep yang berbeda-beda terkait dengan blended learning. Konsep-konsep tersebut adalah: 1) blended learning adalah model kombinasi atau campuran dari teknologi berbasis web (seperti kelas virtual dan belajar mandiri), 2) blended learning adalah gabungan dari berbagai pendekatan pedagogis (seperti konstruktivisme, behaviorisme, kognitivisme) untuk menghasilkan hasil belajar yang optimal dengan atau tanpa teknologi pembelajaran, 3) blended learning adalah segala bentuk penggabungan teknologi pembelajaran (seperti videotape, CD-ROM, film, dan pembelajaran berbasis web) dengan pembelajaran face-to-face, 4) blended learning adalah penggabungan atau 
pencampuran teknologi pembelajaran dengan tugas-tugas kerja nyata dalam rangka untuk menciptakan dampak yang harmonis dalam sebuah pembelajaran atau pekerjaan.

Dari empat konsep blended learning tersebut di atas, konsep pembelajaran blended learning yang digunakan dalam penelitian ini adalah konsep yang ke tiga, yaitu segala bentuk penggabungan teknologi pembelajaran (seperti videotape, CD-ROM, film, dan pembelajaran berbasis web) dengan pembelajaran face-to-face.

Blended learning dihasilkan dari penggabungan atau pencampuran berbagai teori belajar yang dapat dideskripsikan dalam gambar berikut (Carman, J.M., 2002):

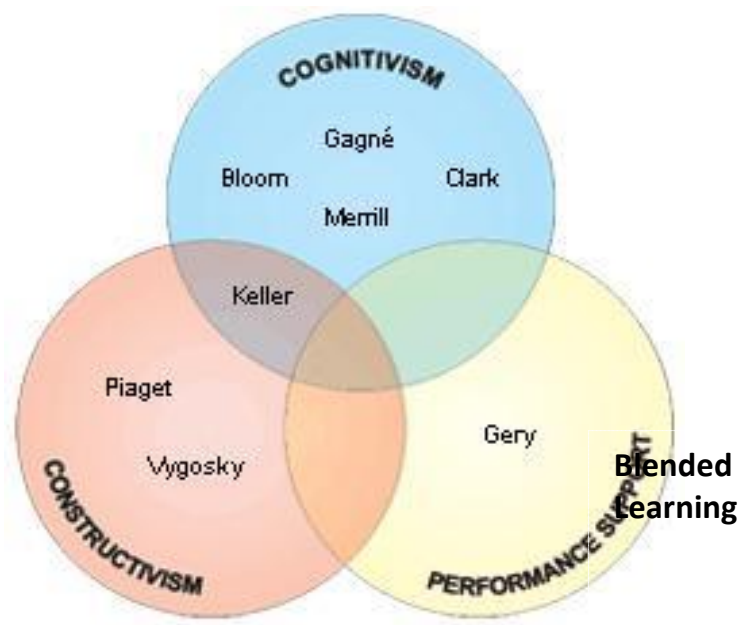

Gambar 1. Teori belajar dalam blended learning

Model desain pembelajaran situasional sangat cocok dengan konsep blended learning. Dengan menerapkan teori belajar Keller, Gagne, Bloom, Merrill, Clark, dan Gery, lima unsur utama muncul sebagai elemen penting dari proses blended learning. Kelima elemen itu adalah: 1) kejadian langsung (live events): Sinkronous, yaitu belajar terbimbing dengan pebelajar berpartisipasi dalam satu waktu yang sama, seperti belajar secara langsung dalam kelas virtual, 2) belajar mandiri (self-paced learning), yaitu pengalaman belajar yang dilakukan pebelajar secara mandiri dengan kecepatan dan waktu yang mereka miliki, seperti belajar interaktif, belajar berbasis internet, atau belajar berbasis CD-ROM, 3) kolaborasi (collaboration), yaitu lingkungan belajar di mana pebelajar saling berkomunikasi satu dengan yang lain, contoh pembelajaran melalui e-mail atau chatting online, 4) asesmen (assessment), yaitu pengukuran pengetahuan pebelajar. Pre-test dapat dilakukan secara live atau melalui belajar mandiri untuk menentukan pengetahuan sebelumnya (prior knowledge) dan posttest dapat dilakukan secara live atau melalui belajar mandiri lanjutan untuk mengukur terjadinya transfer belajar, 5) materi pendukung kinerja (performance support materials), yaitu materi-materi yang digunakan sebagai referensi dalam meningkatkan daya ingat dan transfer belajar, termasuk download PDA, referensi cetak, ringkasan, dan alat bantu belajar.

Sintaks atau langkah-langkah strategi pembelajaran blended learning yang digunakan dalam penelitian ini adalah merujuk pada langkah-langkah pembelajaran berbasis komputer yang digagas oleh Gagne, Wager, Golas, \& Keller (2005), sebagai berikut: 1) mendapatkan perhatian (gaining attention), 2) menginformasikan tujuan pembelajaran kepada pebelajar (informing learner of lesson objective), 3) menstimulasi dengan mengingatkan kembali pelajaran sebelumnya (stimulating recall of prior learning), 4) mempresentasikan stimulus dengan tampilan yang berbeda (presenting stimuli with distinctive feature), 5) membimbing pembelajaran (guiding learning), 6) memberi petunjuk kinerja (eliciting performance), 7) memberikan umpan balik yang informatif (providing informative feedback), 8) menilai kinerja (assessing performance), 9) meningkatkan ingatan dan transfer belajar (enhancing retention and learning transfer), Memberikan beberapa contoh tambahan dalam bentuk yang bervariasi. 
Kata "locus" berarti lokasi atau tempat. Locus of control adalah sebuah kepribadian seseorang yang senantiasa mangaitkan tanggung jawab kegagalan atau keberhasilannya pada faktor internal atau faktor eksternal. Seseorang yang mempunyai internal locus of control berarti seseorang yang mempunyai kepercayaan bahwa keberhasilan atau kegagalannya disebabkan oleh usaha atau kemampuannya sendiri. Sebaliknya, seseorang yang mempunyai external locus of control berarti seseorang yang mempunyai kepercayaan bahwa faktorfaktor luar seperti keberuntungan, tugas yang sulit, atau perilaku orang lain yang menyebabkan keberhasilan atau kegagalannya (Slavin, 94).

Kata internal dan eksternal dalam locus of control merepresentasikan rangkaian bukan tipologi. Internal locus of control cenderung mengaitkan hasil dari suatu peristiwa kepada kontrol diri sendiri. Seseorang yang memiliki internal locus of control percaya bahwa hasil dari tindakannya adalah merupakan hasil dari kemampuannya sendiri. Mereka percaya bahwa setiap kerja keras mereka akan membuat mereka mendapatkan hasil yang positif. Mereka juga percaya bahwa setiap tindakan memiliki konskuensi yang dapat membuat mereka menerima kenyataan bahwa segala sesuatu yang terjadi tergantung pada keinginan mereka untuk mengontrol hal tersebut atau tidak. External locus of control cenderung mengaitkan hasil dari sebuah peristiwa kepada keadaan-keadaan eksternal. Seseorang yang memiliki external locus of control cenderung percaya bahwa sesuatu yang terjadi pada hidup mereka adalah di luar kontrol mereka. Bahkan, tindakan mereka sendiri adalah hasil dari faktorfaktor eksternal seperti nasib, keberuntungan, atau pengaruh kekuatan orang lain (April, Dharani, \& Peters, 2012).

Gagasan tentang locus of control didasarkan pada teori belajar sosial. Teori belajar sosial menyatakan bahwa ekspektasi akan dikuatkan kembali ketika peristiwa atau perilaku yang diharapkan menjadi terwujud di masa yang akan datang. Dengan kata lain, jika seseorang mengharapkan sesuatu terjadi dan memang terjadi, maka harapannya menjadi lebih kuat. Jika harapannya tidak terjadi, maka ekspektasinya menjadi lemah. Intinya, "kontrol" meliputi segala sesuatu yang membuat orang memiliki kekuatan. Alasannya adalah bahwa individu yang percaya bahwa perilaku atau karakteristik mereka menentukan atau menyebabkan peristiwa adalah ciri yang dimiliki internal locus of control. Di sisi lain, seseorang yang berpikir bahwa reinforcement mengikuti sebuah tindakan adalah tidak seluruhnya tergantung pada tindakannya sendiri tetapi disebabkn oleh perasaan seperti keberuntungan, nasib, dan faktor lain di luar kontrol dirinya merupakan external locus of control (Yemen \& Clawson, 2003).

Locus of control merupakan variabel kondisi. Degeng (1989c) menyatakan bahwa variabel kondisi pembelajaran adalah faktor yang mempengaruhi efek metode dalam meningkatkan hasil pembelajaran. Semua variabel pembelajaran yang tidak dapat dimanipulasi dan, karena itu, harus diterima sebagai adanya oleh perancang pembelajaran, diklasifikasikan ke dalam variabel kondisi pembelajaran. Yang dimasukkan ke dalam klasifikasi variabel ini adalah tujuan pembelajaran, karakteristik bidang studi, kendala, dan karakteristik pebelajar. Kondisi belajar pebelajar diklasifikasikan menjadi kondisi belajar internal dan kondisi belajar eksternal. Kondisi belajar internal mengacu kepada perolehan dan penyimpanan kapabilitas-kapabilitas yang telah dipelajari pebelajar yang mendukung belajar kapabilitas lainnya, sedangkan kondisi belajar eksternal mengacu kepada berbagai cara yang dirancang untuk memudahkan proses-proses internal dalam 
diri pebelajar ketika belajar. Jadi, locus of control dalam penelitian ini adalah bagian dari variabel kondisi pembelajaran khususnya pada dimensi karakteristik pebelajar.

Karakteristik pebelajar adalah aspek-aspek atau kualitas perseorangan pebelajar. Aspek-aspek ini bisa berupa bakat, motivasi belajar, atau kemampuan awal (hasil belajar) yang telah dimilikinya. Karakteristik pebelajar akan amat berpengaruh dalam pemilihan strategi pengelolaan, yang berkaitan dengan bagaimana menata pembelajaran, khususnya komponen-komponen strategi pembelajaran, agar sesuai dengan karakteristik perseorangan pebelajar (Degeng, 1989c).

Locus of control dipilih sebagai variabel moderator atau variabel yang turut serta mempengaruhi pemilihan strategi pembelajaran (blended learning) disebabkan oleh adanya beberapa persamaan karakteristik, yaitu: 1) locus of control merupakan variabel kondisi yang berupa karakteristik pebelajar yang selalu mengaitkan tanggung jawab keberhasilan dan kegagalan belajarnya pada faktor internal atau faktor eksternal, sedangkan strategi blended learning cenderung pada pembelajaran mandiri yang tentu berdampak pada kecenderungan tanggung jawab keberhasilan dan kegagalan belajar secara individual, 2) selain kemampuan, locus of control merupakan prediktor yang paling penting bagi prestasi akademik pebelajar (Brookover et al., 1979), 3) untuk mendapatkan performansi dan hasil belajar yang baik di kelas, pembelajar tidak hanya perlu memberikan strategi pembelajaran yang baik, tetapi pembelajar juga perlu memperhatikan keunikan karakter dan perbedaan individual pebelajar (Dunn, 2001), sedangkan Schunk, Pintrich, \& Meece (2010) menjelaskan bahwa salah satu perbedaan individual (individual differences) yang paling konsisten terkait dengan pembentukan atribusi individu adalah locus of control.
Yemen \& Clawson (2003) menjelaskan indikator internal locus of control dan external locus of control yang telah dikembangkan oleh Terry F. Pettijohn adalah sebagai berikut: 1) cara seseorang mengontrol lingkungan (controlling one's environment), 2) kontrol diri (control of self), 3) kemampuan untuk mempengaruhi orang lain (ability to influence others), 4) motivasi dan prestasi (motivation and achievement).

Hasil penelitian yang dilakukan oleh Ellis \& Calvo (2007) menunjukkan bahwa sistem pembelajaran campuran (blended) yang terdiri dari gabungan antara dotLRN, face-to-face dan didukung oleh learning management systems (LMS) dengan segala ICT menjadi signifikan dan bermanfaat untuk dilakukan di universitas.

Dalam konteks blended learning, hasil penelitian menunjukkan bahwa interaksi, outeraksi, dan inter-aksi mempunyai hubungan yang positif. Lebih penting lagi, adalah bahwa kecenderungan kegiatan intra-aksi menempati level yang lebih tinggi terhadap pencapaian belajar yang lebih tinggi adalah sangat jelas. Hal ini konsisten dengan pandangan umum bahwa kegiatan intra-aksi seperti membuat catatan (note-taking) dapat mendorong untuk belajar. (Hwang, et.al., 2009).

Studi yang dilakukan oleh Hughes dan Hagie (2005) menemukan bahwa partisipasi pebelajar dalam pembelajaran online di kelas menunjukkan keberhasilan pebelajar berkaitan dengan penguasaan isi materi pelajaran dan memperlihatkan bahwa diskusi online asychronous memperkenalkan perbaikan diri pada individu.

Dziuban, Hartman, \& Moskal (2004) melaporkan rata-rata keberhasilan mahasiswa dengan perkuliahan melalui blended learning lebih tinggi jika dibandingkan dengan perkuliahan tatap muka atau sepenuhnya online untuk semua etnis. Ketika dibandingkan tingkat retensinya secara keseluruhan pada modus yang lain (tatap muka), perkuliahan dengan blended learning secara umum 
tingkat retensinya setara dengan pebelajar yang melaksanakan perkuliahan tatap muka.

Beberapa peneliti telah menemukan bahwa pebelajar yang mempunyai internal locus of control telah mendapatkan peringkat dan skor hasil belajar yang lebih tinggi dibanding dengan pebelajar yang mempunyai external locus of control meskipun mereka memiliki intelegensi yang sama (Lefcourt, 1976; Nowicki et al., 1978; Wilhite, 1990). Brookover et al., (1979) menemukan bahwa selain kemampuan, locus of control merupakan prediktor yang paling penting bagi prestasi akademik pebelajar.

Penelitian yang dilakukan oleh Akin (2010) terhadap 627 mahasiswa Universitas Sakarya Turki menyatakan bahwa academic locus of control mempengaruhi ketercapaian tujuan pembelajaran secara langsung. Mahasiswa yang memiliki skor external academic locus of control lebih tinggi akan lebih memungkinkan untuk mengadopsi LVGO, PPGO, PVGO dari pada mahasiswa yang memiliki skor tinggi pada internal academic locus of control. Sebaliknya, mahasiswa yang memiliki skor tinggi pada internal academic locus of control lebih memungkinkan untuk mengadopsi LPGO dan LVGO dari pada mahasiswa yang memiliki skor tinggi pada external academic locus of control.

Locus of control dijadikan sebagai dasar untuk mempengaruhi hasil belajar, motivasi dan perilaku. Pebelajar yang percaya bahwa mereka mempunyai kontrol yang kuat terhadap keberhasilan dan kegagalan mereka, cenderung lebih termotivasi untuk menyelesaikan tugas akademis, mencurahkan segala usaha, dan tetap mengerjakan materi yang sulit. Terdapat korelasi yang positif antara internal locus of control, motivasi, dan prestasi belajar di sekolah (Phares, 1976).

\section{TUJUAN PENELITIAN}

Pertama, penelitian ini bermaksud menguji perbedaan perolehan hasil belajar (mengingat dan memahami konsep dan fakta) mata kuliah Sejarah Pendidikan Islam antara mahasiswa yang diberi perlakuan melalui strategi pembelajaran blended learning dan strategi pembelajaran face to face. Kedua, menguji perbedaan perolehan hasil belajar (mengingat dan memahami konsep dan fakta) mata kuliah Sejarah Pendidikan Islam antara mahasiswa yang memiliki internal locus of control dengan mahasiswa yang memiliki eksternal locus of control. Ketiga, menguji interaksi antara strategi pembelajaran blended learning, strategi pembelajaran face to face, dan locus of control mahasiswa terhadap perolehan hasil belajar (mengingat dan memahami konsep dan fakta) mata kuliah Sejarah Pendidikan Islam. Dengan demikian, tujuan penelitian ini adalah menentukan pengaruh utama (main effect) dan pengaruh interaksi (interaction effect) variabel perlakuan terhadap hasil belajar mata kuliah Sejarah Pendidikan Islam pada mahasiswa fakultas Tarbiyah dan Keguruan semester III di UIN Sunan Ampel Surabaya.

\section{METODE}

Penelitian ini menggunakan pendekatan kuantitatif dengan jenis penelitian quasi-eksperimen. Penelitian quasi-ekperimen berusaha mencari keterkaitan hubungan suatu variabel tertentu (Gall et al., 2003), dan berupaya untuk mengungkapkan hubungan sebab akibat dengan cara melibatkan kelompok kontrol di samping kelompok eksperimental (Degeng, 2000b). Penelitian ini menggunakan rancangan a factorialized (2x2) version of nonequivalent control group design (Tuckman, 1999 dan Allen \& Yen, 1979). Metode ini dipilih karena penentuan kelompok-kelompok penerima perlakuan baik kelompok eksperimen maupun kelompok kontrol tidak dapat dilakukan atau dipilih secara acak untuk 
dilibatkan dalam kelompok eksperimen maupun kelompok kontrol, sehingga yang dimungkinkan hanya penentuan perlakuan secara acak (random assignment to treatment).

Dalam konteks penelitian ini, peneliti menggunakan kelompok utuh (intact group) dikarenakan adanya kesangsian tentang kesepadanan (equivalence) kelompok sebelum eksperimen dimulai (Salkind, 2006). Kesangsian terhadap kesepadanan ini menyebabkan desain ini disebut nonequivalent control group design. Hal ini dengan serta merta menurunkan kekuatan rancangan untuk menetapkan hubungan kausal.

Rancangan penelitian a factorialized (2x2) version of nonequivalent control group design dapat ditunjukkan dalam gambar 2 berikut:

\begin{tabular}{cccc} 
Pre-test & \multicolumn{4}{c}{ Treatment } \\
$\mathrm{O}_{1}$ & Post-test \\
& $\mathrm{O}_{2}$ & $\mathrm{X}_{1}$ & $\mathrm{Z}_{1}$ \\
$\mathrm{O}_{3}$ & & $\mathrm{X}_{2}$ & $\mathrm{Z}_{1}$ \\
$\mathrm{O}_{5}$ & $\mathrm{O}_{4}$ & $\mathrm{X}_{1}$ & $\mathrm{Z}_{2}$ \\
$\mathrm{O}_{7}$ & $\mathrm{O}_{6}$ & & \\
& & $\mathrm{X}_{2}$ & $\mathrm{Z}_{2}$ \\
& $\mathrm{O}_{8}$ & &
\end{tabular}

Gambar 2. Rancangan Penelitian: The factorialized $2 \times 2$ version of nonequivalent control group

Gambar 2 menunjukkan prosedur quasi-eksperimen untuk desain faktorial $2 \times 2$. Simbol O dengan indeks $1,3,5,7$ dalam gambar tersebut adalah pengamatan hasil pre-test tentang hasil belajar mata kuliah Sejarah Pendidikan Islam. Simbol $\mathrm{O}$ dengan indeks 2,4,6,8 adalah pengamatan hasil post-test tentang hasil belajar mata kuliah Sejarah Pendidikan Islam. Simbol $\mathrm{X}$ adalah strategi pembelajaran dengan $\mathrm{X}_{1}$ merupakan strategi pembelajaran blended learning dan $\mathrm{X}_{2}$ strategi pembelajaran Face to face yang diperlakukan pada mahasiswa yang memiliki internal locus of control $\left(\mathrm{Z}_{1}\right)$ dan external locus of control.

Rancangan penelitian di atas digunakan untuk menemukan pengaruh utama (main effect) dan pengaruh interaksi (interaction effect) antara semua variabel. Pengaruh utama dan pengaruh interaksi dari suatu variabel tertentu dapat dilihat dengan menggunakan desain faktorial $2 \times 2$. Desain faktorial diartikan sebagai struktur penelitian, dimana dua variabel bebas atau lebih saling diperhadapkan untuk mengkaji akibat-akibatnya secara mandiri dan interaktif terhadap suatu variabel terikat (Kerlinger, 1986; Sevilla, 1993; dan Gall et al., 2003). Desain faktorial membagi kelompok-kelompok berdasarkan jumlah macam perlakuan dan macam kelompok yang akan diteliti.

Variabel dalam penelitian ini meliputi tiga variabel, yaitu: 1) variabel bebas, yakni strategi pembelajaran (strategi pembelajaran blended learning dan strategi pembelajaran face to face), 2) variabel moderator, yakni locus of control, dan 3) variabel terikat, yakni hasil belajar mata kuliah Sejarah Pendidikan Islam. Variabel strategi pembelajaran memiliki dua dimensi yaitu strategi pembelajaran blended learning sebagai kelompok perlakuan dan strategi pembelajaran face to face sebagai kelompok kontrol. Variabel moderator terdiri atas dua dimensi, yaitu internal locus of control dan external locus of control.

Subjek penelitian ini adalah mahasiswa fakultas Tarbiyah dan Keguruan prodi Pendidikan Agama Islam (PAI) dan prodi Pendidikan Guru MI (PGMI) semester III. Pemilihan mahasiswa prodi PAI dan PGMI didasarkan pada beberapa kesamaan karakteristik, yaitu: kedua prodi tersebut berada pada jurusan yang sama yaitu jurusan pendidikan Islam, kedua prodi tersebut adalah prodi yang paling diminati di fakultas Tarbiyah dan Keguruan UIN Sunan Ampel Surabaya, dan mahasiswa kedua prodi tersebut sedang menempuh kompetensi dasar mata kuliah Sejarah 
Pendidikan Islam yang sedang diteliti.

Instrumen yang digunakan dalam penelitian ini dikelompokkan menjadi 2 (dua) jenis, yaitu: 1) instrumen untuk mengukur locus of control, 2) instrumen untuk mengukur perolehan hasil belajar mata kuliah Sejarah Pendidikan Islam.

Instrumen yang digunakan untuk mendapatkan informasi tentang locus of control mahasiswa dikembangkan dari indikator locus of control yang dikemukakan oleh Terry F. Pettijohn (dalam Yemen \& Clawson, 2003) meliputi: a) cara seseorang mengontrol lingkungan (controlling one's environment), b) kontrol diri (control of self), c) kemampuan untuk menpengaruhi orang lain (ability to influence others), d) motivasi dan prestasi (motivation and achievement).

Instrumen locus of control terdiri dari 18 item pernyataan dengan menggunakan skala likert. Terdapat lima pilihan jawaban, yaitu: sangat setuju, setuju, ragu-ragu, tidak setuju, dan sangat tidak setuju. Untuk pernyataan favorable, angka tertinggi 5 diberikan pada jawaban "sangat setuju" dan angka terendah 1 diberikan bagi jawaban "sangat tidak setuju." Sedangkan untuk pernyataan unfavorable, angka tertinggi 5 diberikan pada jawaban "sangat tidak setuju" dan angka terendah 1 diberikan bagi jawaban "sangat setuju." Semakin tinggi skor yang diperoleh responden berarti semakin menunjukkan kecenderungan pada internal locus of control dan sebaliknya semakin rendah skor yang diperoleh responden berarti semakin menunjukkan kecenderungan pada external locus of control.

Setelah proses alih bahasa dan telah mendapatkan validasi dari expert judgment, instrumen tersebut diujicobakan kepada responden yang berasal dari luar subjek penelitian. Data hasil ujicoba kemudian dianalisis validitasnya dengan menggunakan metode summated rating untuk menentukan skala yang ditetapkan terpenuhi atau tidak, dengan deviasi normal yang dikembangkan oleh Edward (dalam Azwar, 2011a).

Analisis validitas berikutnya adalah uji validitas konstruk dengan menggunakan teknik item-total correlation terhadap keseluruhan item pernyataan yang telah memenuhi skala yang ditetapkan. Kriteria keputusan persyaratan yang ditetapkan yaitu 0.500. Artinya, jika terdapat item pernyataan yang memperoleh skor di bawah 0,500, maka item pernyataan tidak digunakan. Proses validasi selanjutnya adalah melakukan analisis faktor untuk memperoleh gambaran konstruk dari kedua dimensi variabel yang ditetapkan dan melakukan analisis reliabilitas dengan menggunakan teknik alpha cronbach.

Hasil uji validitas terhadap instrumen angket locus of control menunjukkan terdapat 2 item pernyataan yaitu nomor 4 , dan 9 yang memperoleh skor 0,285 , dan 0,244 . Nomor item-item pernyataan tersebut lebih kecil daripada 0,500 , sehingga dinyatakan gugur karena tidak memenuhi kriteria persyaratan yang ditetapkan. Hal ini didasarkan pada pendapat Ardhana (2013), bahwa jika skor corrected item-total correlation yang diperoleh kurang dari 0,400-0,500 pada taraf signifikansi 0,05 , maka itemitem tersebut tidak dapat digunakan. Dengan demikian item pernyataan locus of control tersisa 18 item yang digunakan dalam penelitian sebenarnya.

Hasil uji reliabilitas terhadap 18 item instrumen locus of control diperoleh koefisien reliabilitas Alpha-Cronbach sebesar 0,781. Angka 0,781 lebih besar daripada 0,70 sebagai angka yang dipersyaratkan (Linn, 1989). Berdasarkan hasil ini, dapat disimpulkan bahwa instrumen locus of control adalah reliable.

Berdasarkan uji asumsi dalam analisis faktor ditemukan uji asumsi locus of control memiliki nilai indeks KMO (Kaiser - Meyer - Olkin) sebesar 0,670 adalah lebih besar daripada 0,50. 
Hal ini telah memenuhi syarat untuk menunjukkan adanya kecukupan ukuran kedekatan sampel. Dari hasil uji Bartlett's test of sphericity diperoleh hasil sebesar 555.806 dengan taraf signifikan $=0,000$. Hasil ini menunjukkan bahwa antar variabel terjadi interdependent pada tingkat significance $<0,05$.

Hasil pengujian pada nilai determinant of correlation matrix dan nilai Bartlett's test of Sphfericity maupun Kaiser - Meyer - Olkin menunjukkan bahwa item-item tersebut telah memenuhi syarat-syarat yang ditentukan untuk dapat menggunakan alat uji analisis faktor. Terakhir, hasil uji Measures of Sampling Adequecy (MSA) memperlihatkan semua variabel yang tertahan dalam model memenuhi syarat MSA yaitu > 0,50 , hal ini menunjukkan bahwa hubungan antar variabel sangat erat.

Pada tahap kedua adalah
melakukan
sekumpulan variabel yang ada, ekstraksi dilakukan dengan menggunakan Principal Component Analysis (PCA) dengan kriteria komunalitas minimal 0,5 , eigenvalue minimal 1 , dan factor loading minimal 0,50. Rotasi faktor menggunakan metode varimax dilakukan untuk lebih memperjelas atau meningkatkan factor loading dari faktor yang terekstrak. Untuk melihat faktor yang terbentuk, dapat dilihat dari output total variance explained sebesar 72,290. Angka tersebut menunjukkan bahwa penelitian ini mampu menjelaskan faktorfaktor yang dipertimbangkan untuk LOC sebesar 72,290\%.

Instrumen untuk mengukur hasil belajar mata kuliah Sejarah Pendidikan Islam adalah instrumen tes. Tes adalah serentetan pertanyaan atau latihan yang digunakan untuk mengukur keterampilan, pengetahuan, intelegensi, dan kemampuan atau bakat yang dimiliki individu atau kelompok (Azwar, 2011b). Dalam hal ini, instrumen tes digunakan untuk mendapatkan informasi tentang hasil belajar mata kuliah Sejarah Pendidikan
Islam baik pada kelompok eksperimen maupun kontrol.

Pengujian persyaratan analisis yang dilakukan yaitu uji normalitas dan homogenitas. Uji normalitas data masing-masing kelompok perlakuan diukur menggunakan KolmogorovSmirnov. Uji homogenitas varian (Test of Homogeneity of Variances) digunakan Levene"s Test of Equality of Error Variances.

Hasil uji normalitas data pada penelitian ini ditemukan bahwa nilai Kolmogorov-Smirnov untuk blended learning adalah 1,075 dan nilai Kolmogorov-Smirnov untuk face to face adalah 0,716. Hasil analisis uji normalitas Kolmogorov-Smirnov (K-S) yang merupakan uji untuk mengetahui apakah subyek penelitian berasal dari populasi dengan distribusi normal, memperlihatkan bahwa perolehan hasil belajar untuk masing-masing strategi pembelajaran blended learning dan strategi pembelajaran face to face menunjukkan angka signifikansi atau probabilitas masing-masing kelompok lebih dari $0,05(\alpha=5 \%)$. Hasil pengujian ini mengandung arti bahwa data perolehan hasil belajar Sejarah Pendidikan Islam pada kelompok eksperimen (strategi pembelajaran blended learning) dan kelompok kontrol (strategi pembelajaran face to face) adalah berdistribusi normal.

Hasil uji homogenitas varian telah ditemukan bahwa nilai probablitias yang dihasilkan adalah 0,278 (> 0,05), sehingga dapat disimpulkan bahwa varian data perolehan hasil belajar mata kuliah Sejarah Pendidikan Islam yang dilakukan melalui strategi pembelajaran blended learning dan data perolehan hasil belajar mata kuliah Sejarah Pendidikan Islam yang dilakukan melalui strategi pembelajaran face to face memiliki varian yang homogen.

\section{HASIL DAN PEMBAHASAN}


Hasil analisis terhadap uji hipotesis 1, yaitu tentang perbedaan perolehan hasil belajar mata kuliah Sejarah Pendidikan Islam antara kelompok pebelajar yang diberi perlakuan dengan menggunakan strategi pembelajaran blended learning dan kelompok pebelajar yang diberi perlakuan dengan menggunakan strategi pembelajaran face to face diketahui bahwa nilai $F_{\text {hitung }}=98,880$ dengan nilai probabilitas $(\mathrm{p})=0,000$. Oleh karena $(\mathrm{p}<$ 0,05), maka Ho ditolak, sehingga hasil pengujian mengandung arti "terdapat perbedaan perolehan hasil belajar mata kuliah Sejarah Pendidikan Islam antara mahasiswa yang diberi perlakuan melalui strategi pembelajaran blended learning dan strategi pembelajaran face to face.

Alasan yang memperkuat mengapa blended learning (face to face, online dan offline) lebih unggul khususnya pada pembelajaran Sejarah Pendidikan Islam dikarenakan blended learning memiliki kombinasi media dalam penyampaian pembelajaran (Graham, 2006) sehingga dapat mengakomodasi berbagai perbedaan preferensi belajar pebelajar. Tidak ada satu metode penyampaian yang ideal bagi seluruh bentuk pembelajaran. Suatu mata pelajaran yang berbeda akan membutuhkan metode pembelajaran yang berbeda. Blended learning menghendaki para profesional pembelajaran untuk mengakomodasi preferensi belajar pebelajar agar lebih tepat khususnya bagi pembelajaran di kelas sebagai pusat pembelajaran. Suatu pendekatan di kelas yang terbaik bagi pembelajaran yang dikombinasikan dengan kepemimpinan instruktur terbaik dengan suatu metode tambahan dalam satu pembelajaran (Wilson \& Smilanich, 2005).

Learning-preference hypothesis beranggapan bahwa setiap orang yang berbeda akan berbeda pula cara belajarnya. Oleh karena itu, cara terbaik untuk menyajikan materi pembelajaran adalah dalam sebanyak mungkin format yang berbeda (Mayer, R.E., 2009). Teori tentang modality effect (pengaruh modalitas belajar) menjelaskan bahwa kapasitas kognitif bisa efektif ditingkatkan jika memori kerja untuk visual dan verbal bisa sama-sama digunakan. Pendeknya, ukuran efektif dari memori kerja bisa ditingkatkan dengan menyajikan informasi dalam mode campuran (auditori dan visual) daripada mode tunggal (Mousavi, Low, \& Sweller, 1995)

Berdasar pada penjelasan tersebut dapat dinyatakan bahwa alasan blended learning menghasilkan perolehan hasil belajar yang secara signifikan lebih baik adalah bahwa blended learning sebagai salah satu strategi pembelajaran campuran atau kombinasi mampu mengakomodasi preferensi belajar pebelajar yang berbedabeda. Gagne, Wager, Golas, \& Keller (2005) menjelaskan bahwa learning style adalah cara belajar yang disukai (learning preference) dan paling efisien bagi individu dalam mempelajari informasi baru.

Faktor pendukung keberhasilan lainnya yakni pada proses pembelajaran mahasiswa secara aktif melakukan kegiatan-kegiatan terintegrasi yang difasilitasi dengan komputer, dan media pembelajaran / CD Pembelajaran (offline). Hal tersebut sejalan dengan apa yang dikemukaan oleh Heinich, Molenda, Russel dan Smaldino (2002) yang menyatakan bahwa sistem komputer (media interaktif) dapat menyampaikan pembelajaran secara individual dan langsung kepada mahasiswa dengan cara berinteraksi langsung dengan mata kuliah yang diprogramkan dalam komputer.

Hasil analisis terhadap uji hipotesis 2, yaitu tentang perbedaan perolehan hasil belajar mata kuliah Sejarah Pendidikan Islam antara kelompok pebelajar yang memiliki internal locus of control dan kelompok pebelajar yang memiliki external locus of control diketahui bahwa nilai $F_{\text {hitung }}=36,950$ dengan nilai probabilitas $(\mathrm{p})=0,000$. Oleh karena $(\mathrm{p}<$ 0,05), maka Ho ditolak. Dengan demikian 
hasil pengujian mengandung arti "Terdapat perbedaan perolehan hasil belajar mata kuliah Sejarah Pendidikan Islam antara mahasiswa yang memiliki internal locus of control dengan mahasiswa yang memiliki external locus of control."

Temuan penelitian ini sejalan dengan teori dan hasil penelitian yang dilakukan sebelumnya. Beberapa peneliti telah menemukan bahwa pebelajar yang mempunyai internal locus of control telah mendapatkan peringkat dan skor hasil belajar yang lebih tinggi dibanding dengan pebelajar yang mempunyai external locus of control meskipun mereka memiliki intelegensi yang sama (Lefcourt, 1976; Nowicki et al., 1978; Wilhite, 1990). Brookover et al., (1979) menemukan bahwa selain kemampuan, locus of control merupakan prediktor yang paling penting bagi prestasi akademik pebelajar.

Penelitian yang dilakukan oleh Akin (2010) terhadap 627 mahasiswa Universitas Sakarya Turki menyatakan bahwa academic locus of control mempengaruhi ketercapaian tujuan pembelajaran secara langsung. Mahasiswa yang memiliki skor external academic locus of control lebih tinggi akan lebih memungkinkan untuk mengadopsi LVGO, PPGO, PVGO dari pada mahasiswa yang memiliki skor tinggi pada internal academic locus of control. Sebaliknya, mahasiswa yang memiliki skor tinggi pada internal academic locus of control lebih memungkinkan untuk mengadopsi LPGO dan LVGO dari pada mahasiswa yang memiliki skor tinggi pada external academic locus of control.

Alasan lain yang sejalan dengan temuan hasil penelitian adalah bahwa Locus of control dijadikan sebagai dasar untuk mempengaruhi hasil belajar, motivasi dan perilaku. Pebelajar yang percaya bahwa mereka mempunyai kontrol yang kuat terhadap keberhasilan dan kegagalan mereka, cenderung lebih termotivasi untuk menyelesaikan tugas akademis, mencurahkan segala usaha, dan tetap mengerjakan materi yang sulit. Terdapat korelasi yang positif antara internal locus of control, motivasi, dan prestasi belajar di sekolah (Phares, 1976).

Locus of control merupakan variabel kondisi pembelajaran yang perlu diperhatikan. Degeng (1989c) menyatakan bahwa variabel kondisi pembelajaran adalah faktor yang mempengaruhi efek metode dalam meningkatkan hasil pembelajaran. Semua variabel pembelajaran yang tidak dapat dimanipulasi dan, karena itu, harus diterima sebagai adanya oleh perancang pembelajaran, diklasifikasikan ke dalam variabel kondisi pembelajaran. Yang dimasukkan ke dalam klasifikasi variabel ini adalah tujuan pembelajaran, karakteristik bidang studi, kendala, dan karakteristik pebelajar. Kondisi belajar pebelajar diklasifikasikan menjadi kondisi belajar internal dan kondisi belajar eksternal. Kondisi belajar internal mengacu kepada perolehan dan penyimpanan kapabilitas-kapabilitas yang telah dipelajari pebelajar yang mendukung belajar kapabilitas lainnya, sedangkan kondisi belajar eksternal mengacu kepada berbagai cara yang dirancang untuk memudahkan proses-proses internal dalam diri pebelajar ketika belajar. Jadi, locus of control dalam penelitian ini adalah bagian dari variabel kondisi pembelajaran khususnya pada dimensi karakteristik pebelajar.

Hasil analisis terhadap uji hipotesis 3 menunjukkan bahwa tidak terdapat interaksi antara strategi pembelajaran dan locus of control terhadap perolehan hasil belajar Sejarah Pendidikan Islam. Hal tersebut didukung dengan hasil perhitungan uji test of between-subject effect yang menunjukkan nilai $\mathrm{p}=0,089$ $(\mathrm{p}>0,05)$. Berdasarkan paparan ini disimpulkan bahwa tidak terdapat interaksi antara strategi pembelajaran dan locus of control terhadap perolehan hasil belajar.

Berkaitan dengan hasil penelitian ini, dapat dimaknai bahwa strategi pembelajaran blended learning memberikan pengaruh yang signifikan terhadap perolehan hasil belajar Sejarah Pendidikan Islam, tanpa 
kontribusi locus of control (LOC). Begitu pula sebaliknya, locus of control (LOC) memberikan pengaruh utama (main effect) secara signifikan terhadap perolehan hasil belajar Sejarah Pendidikan Islam tanpa kontribusi strategi pembelajaran.

Dukungan teoritis dan empiris mengenai pengaruh kedua variabel utama yaitu strategi pembelajaran dan LOC secara sendiri-sendiri terhadap hasil belajar berimplikasi terhadap lemahnya pengaruh interaksi. Artinya bahwa lemahnya interaksi ini dilandasi asumsi bahwa pengaruh strategi pembelajaran tidak dimoderasi oleh perbedaan LOC. Dalam ungkapan lain, pengaruh strategi pembelajaran terhadap perolehan hasil belajar Sejarah Pendidikan Islam akan diperlemah oleh LOC, begitu sebaliknya, pengaruh perbedaan LOC terhadap perolehan hasil belajar akan diperlemah oleh strategi pembelajaran. Hal ini berimplikasi pada rekomendasi pembelajaran blended learning di UIN Sunan Ampel Surabaya, bahwa jika digunakan strategi pembelajaran blended learning, maka tidak harus menghiraukan locus of control karena di antara keduanya tidak terdapat interaksi terhadap perolehan hasil belajar.

Catatan dalam penelitian ini adalah terkait dengan lemahnya pengaruh interaksi antara strategi pembelajaran dengan LOC sebagai variabel bebas terhadap variabel terikat. Hal ini tampak berbeda dengan hasil penelitian sebelumnya yaitu hasil penelitian Sukisno (2013) yang menyatakan bahwa terdapat interaksi antara Strategi pembelajaran VCT dan locus of control. Perbedaan ini dapat disebabkan oleh beberapa hal seperti perbedaan subjek penelitian, perbedaan instrumen penelitian, perbedaan materi ajar dalam penelitian, perbedaan variabel terikat yang diteliti, atau perbedaan teknik penelitian. Karena itu perlu kajian mendalam terkait pengembangan instrumen, studi lanjut terhadap lokasi dan subjek penelitian yang berbeda dan jenjang pendidikan yang berbeda dengan teknik pengumpulan data yang lebih variatif misalnya teknik pengumpulan data kualitatif maupun mix method.

\section{SIMPULAN DAN SARAN}

Berdasarkan deskripsi hasil penelitian, pengujian hipotesis, dan pembahasan dapat disampaikan beberapa simpulan hasil penelitian sebagai berikut:

1. Perolehan hasil belajar (mengingat dan memahami konsep dan fakta) mata kuliah Sejarah Pendidikan Islam antara kelompok mahasiswa yang dibelajarkan dengan strategi pembelajaran blended learning (face to face, online dan offline) dan strategi pembelajaran face to face (tatap muka secara langsung) menunjukkan adanya perbedaan yang signifikan. Penggunaan strategi pembelajaran blended learning (face to face, online dan offline) secara signifikan lebih unggul dari strategi pembelajaran face to face (tatap muka secara langsung).

2. Perolehan hasil belajar (mengingat dan memahami konsep dan fakta) mata kuliah Sejarah Pendidikan Islam antara kelompok mahasiswa yang memiliki internal locus of control dan kelompok mahasiswa yang memiliki external locus of control menunjukkan adanya perbedaan yang signifikan. Mahasiswa yang memiliki internal locus of control memberikan perolehan hasil belajar yang lebih baik daripada kelompok mahasiswa yang memiliki external locus of control.

3. Tidak terdapat pengaruh interaksi antara strategi pembelajaran blended learning (face to face, online dan offline), strategi pembelajaran face to face (tatap muka secara langsung), dan locus of control 
terhadap hasil belajar (mengingat dan memahami konsep dan fakta) Sejarah Pendidikan Islam. Tidak adanya interaksi menunjukkan bahwa variabel locus of control tidak mengubah pengaruh strategi pembelajaran terhadap perolehan hasil belajar Sejarah Pendidikan Islam dan sebaliknya.

\section{SARAN-SARAN}

Saran-saran yang disampaikan pada bagian tulisan ini dikelompokkan menjadi dua bagian, yaitu saran-saran yang terkait dengan pemanfaatan hasil penelitian dalam pembelajaran mata kuliah Sejarah Pendidikan Islam, dan saran-saran terkait dengan penelitian lebih lanjut. Terkait dengan pemanfaatan hasil penelitian, saransaran yang diberikan adalah: 1) penerapan strategi blended learning tidak harus mempertimbangkan locus of control karena antara keduanya tidak terdapat pengaruh interaksi terhadap perolehan hasil belajar. Namun, secara terpisah locus of control merupakan variabel kondisi yang harus dipertimbangkan dalam mendesain pembelajaran karena memiliki pengaruh yang signifikan secara mandiri terhadap perolehan hasil belajar, 2) sarana dan prasarana merupakan hal yang sangat penting dalam penerapan strategi pembelajaran blended learning, fasilitas komputer dan laptop yang harus dimiliki oleh mahasiswa atau ketersediaan laboratorium komputer serta jaringan internet yang cukup memadai. Serta penguasaan dan pengelolaan pembelajaran yang harus dipahami dengan baik oleh dosen maupun mahasiswa.

Saran-saran berikut ini ditujukan kepada para praktisi pendidikan dan dosen yang ingin melaksanakan penelitian lebih lanjut berkenaan dengan hasil penelitian ini. 1) Penelitian ini perlu direplikasi di perguruan tinggi untuk menentukan apakah akan mendapatkan hasil temuan yang sama. Karena penelitian ini dilakukan hanya pada satu perguruan tinggi saja, maka penelitian lebih lanjut dapat dilakukan pada beberapa perguruan tinggi lainnya, terutama bagi yang memiliki metode yang berbeda untuk mengembangkan dan menerapkan strategi pembelajaran blended learning, 2) hasil penelitian ini telah menunjukkan bahwa tidak terdapat interaksi antara strategi pembelajaran blended learning, face to face, dan locus of control terhadap perolehan hasil belajar mahasiswa. Hasil ini tampak berbeda dengan hasil penelitian sebelumnya. Oleh karena itu, disarankan untuk melakukan penelitian lanjutan tentang hal tersebut dengan subjek penelitian, teknik penelitian, dan instrumen penelitian yang berbeda agar hasil penelitian tersebut dapat teruji kebenarannya.

\section{DAFTAR RUJUKAN}

Akin, A. (2010). Achievement Goals and Academic Locus of Control: Structural Equation Modeling. Egitim Arastirmalari-Eurasian Journal of Education Research, 38, 1-18.

Allen, M. \& W.M. Yen. (1979). Introduction to Measurement Theory. California: Brooks/Cole Publishing Company.

April, K.A, Dharani.B, \& Peters.K. (2012). Impact of Locus of Control Expectancy on Level of WellBeing. Review of European Studies, 4 (2), 125-126

Ardhana, W. (1987). Bacaan Pilihan dalam Metode Penelitian Pendidikan. Jakarta: P2LPTK Ditjen Dikti Depdikbud.

Azwar, S. (2011a). Penyusunan Skala Psikologi. Yogyakarta: Pustaka Pelajar.

Azwar, S. (2011b). Tes Prestasi: Fungsi 
dan Pengembangan Pengukuran Prestasi Belajar. Yogyakarta: Pustaka Pelajar.

Bender, D. M., \& Vredevoogd, J. D. (2006). Using Online Education Technologies to Support Studio Instruction. Educational Technology \& Society, 9 (4), 114122.

Bonk, C.J \& Graham, C.R. (2006). The Handbook of Blended Learning. San Francisco: John Wiley \& Sons, Inc.

Brookover, W., Beady, C. Flood, P. Schweister, J, \& Wisenbaker, J. (1979). School Social System and Student Achievement. New York: Praeger.

Carman, J. M. (2002). Blended Learning Design; Five Key Ingredient. New York: KnowledgeNet.

Chew, E. (2008). Book review: Blended Learning Tools for Teaching and Training. Educational Technology \& Society, 11 (2), 344-347.

Degeng, I.N.S. (2000b). Pelatihan Pekerti. Malang: Universitas Negeri Malang Press.

Degeng, I.N.S. (1989c). Ilmu Pengajaran Taksonomi Variable. Jakarta: Departemen Pendidikan dan Kebudayaan Dirjen Dikti P2LPTK.

Driscoll, M. (2002a). Blended Learning: Let's get beyond the hype. Diakses dari http://www.elearningmag.com/elea $\underline{\text { rning/article/articleDetail.jsp?id=11 }}$ 755

pada tanggal 3 Maret 2011

Dunn, R. (2001). Learning Style
Differences of Nonconforming Middle-School Student. NASSP Bulletin, 2001; 85; 68. Diakses darihttp://bul.sagepub.com

Erez,T.A.J.A, Bono J.E, dan Thoresen C.J. (2002). Are Measures of SelfEsteem, Neuroticism, Locus of Control, and Generalized SelfEfficacy Indicators of a Common Core Construct?. Journal of Personality and Social Psychology, 2002, vol. 83, No. 3, 693-710.

Gagne, R.M, Wager, W.W, Golas, K.C \& Keller, J.M. (2005). Principles of Instructional Design. Belmont: Wadsworth.

Gall, M.D., Gall, J.P. \& Borg, W.R. (2003). Educational Research: An Introduction. Seven ${ }^{\text {th }}$ Edition. Boston: Pearson Education, Inc.

Graham, C. R. (2006). Blended Learning systems: Definiton, current trends, and future directions. Dalam C. J. Bonk and C. R. Graham (Eds.), The handbook of blended learning:Global persepctives, local designs.San Francisco:Pfeiffer. pp. 3-21.

Heinich, R., Molenda, M., Russell, J. D., \& Smaldino, S. E. (2002). Instructional Media and Technologies for Learning. Upper Saddle River, NJ: Pearson Education.

Hwang, W.-Y., Hsu, J.-L., Tretiakov, A., Chou, H.-W., \& Lee, C.-Y. (2009). Intra-action, Interaction and Outeraction in blended learning environments. Educational Technology \& Society, 12 (2), 222239. 
Inoue, Y. (2010). Cases on online and blended learning technologies in higher education : concepts and practices. New York: IGI Global

Kerlinger, F.N. (1986). Asas-asas Penelitian Behavioral. Terjemahan oleh Landung R. Simatupang. 1990. Yogyakarta: Gajah Mada University Press.

Lefcourt, H. (1976). Locus of Control; Current Trends in Research and Theory. Hillsdale, N.J.: Erlbaum.

Linn, R. L., (1989). Educational Measurement. New York: American Council on Education and McMilan Publishing.

Mayer, R.E. (2009). Multi-Media Learning; Prinsip-prinsip dan Aplikasi. Ter. Teguh Wahyu Utomo. Yogyakarta: Pustaka Pelajar.

Mousavi, S., Low, R., \& Sweller, J. (1995). Reducing Cognitive Load by Mixing Auditory and Visual Presentation Modes. Journal of Educational Psychology, 87, 319334.

Phares, E.J. (1976). Locus of Control in Personality. Morristown, NJ.:General Learning Press

Qasim, A. (2014). Learning from the Past; A Contentious Issue?. Jurnal Kajian Sejarah \& Pendidikan Sejarah, 2 (1) Maret 2014. Hlm. 6

Salkind, J. N. (2006). Encyclopedia of Educational Psychology. New York: Sage Publications.

Schunk, D.H, Pintrich, P.R, \& Meece, J.L. (2010). Motivation in Education; Theory, Research, and Applications. New Jersey: Pearson
Education, Inc.

Sevilla, C.G. (1993). Pengantar Strategi Penelitian. Jakarta: UI Press.

Slavin, R.E. (1994). Educational Psychology; Theory and practice. Needham Heights: Allyn and Bacon.

Smaldino, S.E., Lowther, D.L, \& Russell, J.D. (2008). Instructional Technology and Media for Learning. New Jersey: Pearson Education, Inc.

So, H.-J., \& Bonk, C. J. (2010). Examining the Roles of Blended Learning Approaches in ComputerSupported Collaborative Learning (CSCL) Environments: A Delphi Study. Educational Technology \& Society, 13 (3), 189-200.

Sukisno. (2013). Pengaruh Strategi Pembelajaran Klarifikasi Nilai dan Locus of Control terhadap Hasil Belajar pendidikan Kewarganegaraan dan kemampuan Berpendapat Mahasiswa. (Disertasi) Program Pascasarjana Universitas Negeri Malang (Tidak Dipublikasikan).

Tuckman, W.B. (1999). Conducting Educational Research: Fifth Edition. New York: Harcourt Brace Jovanovich, Publisher.

Wilhite, S.C. (1990). Self-Efficacy, Locus of Control, Self-Assessment of Memory Ability, and Study Activities as Predictors of College Course Achievement. Journal of Educational Psychology Review, 82 (4), 696-700.

Williams, P. (2010). Beyond Control:Will Blended Learning Subvert National Curricula? Dalam Eugenia M.W. 
Ng. (Ed.). Comparative blended

learning practices and

environments. New York: IGI

Global.

Yemen, G \& Clawson, J.G. (2003). Locus

of Control. Charlottesville: the

University of Virginia Darden

School Foundation. 